\title{
Analysis of Racism Discrimination in "12 Years A Slave" Encountered by Solomon Northup
}

\author{
Imran Anshari ${ }^{1}$ and Mutmainnah Marsuki ${ }^{2}$ \\ 1,2 Department of English Language Studies, Universitas Hasanuddin, Makassar, Indonesia \\ *imran.anshari.a@gmail.com
}

\begin{abstract}
This research aims to find racism discrimination encountered by Solomon Northup in "12 Years a Slave". This novel talks about Solomon Northup's experience as a slave for 12 years. This research is using the descriptive analysis method and uses the genetic structuralism approach by Lucian Goldman to describe the data. Racism concept uses Rodney Clark concept to classify racism act in the movie. The result of this research is classified kinds of racism. Kind of Discrimination is classified into two groups, verbal and non-verbal racism. Because racism discrimination is the top social issue, the writers hope that research about racism can be continued to get a better comprehensive result..
\end{abstract}

Key words: Discrimination, genetic structuralism, racism.

\section{Introduction}

Literature as writing makes people out of social constraints existing restrictions on the reader and focus on the work that they read. The ability of literature to engage the reader out of their historical conditions ultimately provides a critical function in the literature [1]. One of critical functions of literature is literature as a language, in this function the language is part of the cultural and important think in communicated to society. Language is one sample of literature and social relationship but that statement was not enough to represent literature as a language in accordance with sociology.

The research of literature is work to explain the effect of society in literature and explain the position of literature in society, in this genre of literature not just reflection of history but the essence and summary of the history. According to Wallek and Warren the first relationship between literature and social is the sociology of the author. This relates to the economic basis of literary production, social background, and status of the authors. The second is the contents of a literary work itself, and other things of interest implicit in the work related to social problems, the latter of the literary works and social impact of literary works [2].

The writers have several reasons why choice 12 years a slave as works that have to analysis. Firstly, 12 Years a Slave brings racism issue, the novel portrays the social condition in that era and can be used as the reference to analyze the social condition. Moreover, the theme of racism 12 years, a slave also shows an economic condition that has a relationship with racism discrimination in the United States. Secondly, the reason why the writers chose 12 years a slave is that it is based on a true story, it was written by Salomon Northup. He is educated of African descent who had 
his own freedom before his kidnapped and was used as a slave. When he succeeded to escape from his master, He wrote a book about his experience as a slave for 12 years. What is the difference between 12 years a slave movie with the other work about racism? The answer is the background of the story when the story was created by Salomon Northup (the main character in 12 years a slave) itself. The experience of the author of 12 years a slave he put into the biography of himself makes the story that he wrote is non-fiction.

The writer states that this research aims at finding out the kind of racism discrimination committed by the European people to the African people in the novel. Then, the writers hope the result of this research is expected to be useful information for another student in having a good comprehension and interest to analyze a novel with another approach and social critic about racism. The result of this research also can be used as a reference for the people who put concern on human rights.

\section{Theoritical Reviews}

There are several prior studies regarding racism. Firstly, [3] in his research journal entitled "Race, Racism, and Discrimination: bridging problems, methods and theory in social psychological research" said that social psychological research on race proves that society and social structure could create individuals possessing particularly typed of ethno racial identities, beliefs, attitudes, and value orientation. At the same time, they show individuals possessing racial psychological attributes and outlook than interact behave in ways that variously instantiate and reinforce, or challenge and transform, extant social structures of race. For instance, the black or negro identic as people who work as labor or another physical activity, that make stereotype to that black people is a race that has a lower position in social structure. That shows how social influences individual, society flow to individual stereotype to the particular group or race. The research of social psychology shows how social structure separated the people in this case between the black and the white. The research which conducted by Lawrence focused on the psychological effect caused by social structure. The pressure of the society makes particular groups of people disturb the research also show how history makes the stereotype to society and influence individuals. Our understanding of the dynamics of race, racism, and discrimination is enriched by studies that aim to bridge otherwise insular intellectual communities defined by narrowly focused problems, single methodologies, or particular theories of the middle range. The research reported in this issue, by engaging in multi-group and cross-national comparisons, using mixed or multiple-method research designs, and taking seriously a target-group/minority-group perspective, points us toward important new advances. We are most likely to make large strides toward formulating well-specified general theory in race, racism, and discrimination when research strategies aimed at building these types of bridges continue and flourish.

Secondly, there is [4] find in "To Kill a Mockingbird" Review, the journal is about Atticus Finch, who appears as an unconventional hero and role model due to his morality rather than his physical capabilities. The theme of morals is apparent throughout the whole novel, especially in relation to religion and the perception of sin. Take Mrs. Dubose, a recovering morphine addict: she vows that she'll die beholden to nothing and nobody. She's pursuing her own dream of being a free human being because she knows deep down that it is right. To Kill a Mockingbird focuses on that gut instinct of right and wrong, and distinguishes it from just following the law. Even the titular quote: "Shoot all the blue jays you want, if you can hit them, but remember it's a sin to kill a mockingbird" is in itself an allegory for this message. Being in itself a generic message, the idea of 'doing what is right' obviously has a different meaning depending on when and where you're reading the book. If you take 1960, when the book was written, America was in a state of ethical development as social inequality was - very - gradually being overcome. Women's rights and black rights movements were beginning to emerge and some campaigned through violence.

Based on research in previous related findings, the writers find that Lawrence, as well as David, analyzes racism. They were talking about the cause of why racism is the main problem in society and affects victims, but both of them was used a different approach. Lawrence used a social-psychology to analyze racism meanwhile David reviewed a literary work titled "To Kill A Mockingbird". Lawrence was concerned about the psychological effect of racism on the victims; how the victims communicated to the social and social pressure the victims. Both problem statements are the main problem in Lawrence's research. David in "To Kill A Mockingbird" review was just concerned with the intrinsic elements of the works. Even using pure structuralism, he tried to describe racism and feminism in one research. the previous findings that related to racism explained by the author have a mutual object to research, however, the writer tries to formulate historical background, the writer of 12 years a slave social background. The difference of this research is extrinsic unsure the author put world vision about the 12 Years A Slave as well as the history.

Racism is the kind of discrimination by a particular race to another race that consider as the lower class in society. Prejudice, discrimination, or antagonism directed against someone of a different race is based on the belief that one's own race is superior (oxford dictionary). Racism is a differentiation action against a particular group of people in society because of differences in physical characteristics. Even American biopsychosocial organizations assume racism more evidence they said that racism is operationally defined as beliefs, attitudes, institutional arrangements, and acts that tend to denigrate individuals or groups of phenotypic characteristics or ethnic group affiliation [5]. This action occurred if a particular race of humans or groups of people think that assume that race or group of its most 
superior to the others. The theory about racism is still developed by the scientist that they try to make a theory that is accepted by society.

Discrimination is a big social problem, the author will separate kind of discrimination according to the reason of racism into its various forms components behaviors was also presented as differential acts such as discrimination by religion, gender, nationality, race, age, caste, disability, employ and language [6]. Discrimination of race has made a margin among the group of people. Even after the world government has launched human rights rules, the condition of racism in some countries has not changed especially in the United States [7]. 12 Years a Slave starts with a brief introduction from Solomon Northup's editor, a white man named David Wilson. Wilson offers basic notes for the peruser, confirming that he precisely took down Northup's dictations and indicating out that Northup's story can be certified by open prove. Northup found himself within the comparatively generous hands of William Passage, a servant who never addressed the slave framework he had acquired, but never abused his slaves either. But before long Passage was in monetary challenges, and sold Northup to the horrendous John Tibeats, a nonsensical, savage man who about slaughtered Northup more than once. After endeavoring to run absent, and being passed to another merciless owner, Northup was sold to Edwin Epps, an intoxicated, twisted bully, who ran the manor where Northup would work until he was at last protected [8].

At last, Wilson pronounces his judgment and reason for this work: "The as it were a protest of the editor has been to provide a loyal history of Solomon Northup's life, as he got it from his lips [9]. In a nutshell, Solomon Northup Day, an annual observance held in July in Saratoga Springs, New York, U.S., in recognition of Solomon Northup, a free farmer, laborer, and musician who was abducted and sold into slavery in 1841 and liberated 12 years later. Northup was born in Schroon (now Minerva), New York, and lived and worked in a variety of towns and villages in the state before moving his family to Saratoga Springs. In 1841, lured to Washington, D.C., with the promise of work, Northup was abducted, and soon thereafter he was sold into slavery in Louisiana [10]. Eventually, a Canadian named Bass came to Epps's manor and was listened to voicing abolitionist assumptions, an unsafe sin within the slaveholding south. Northup's account stages a wrangle about between Bass and Epps: Epps offers the standard justification for slavery, those dark individuals were normally inhuman and insensible, and in this way deserved oppression [11].

\section{Methodology}

In this research, the writer uses the descriptive method by using the genetic structuralism approach by Lucian Goldmann [6] and social theory to describe the racist discrimination in 12 years a slave movie and the effect to victims of racism that influences the social structure in the United States. The data that was used in this research were namely; the novel, thesis, journal, and article. The primary data was the movie as the main object of the research and the secondary data were the thesis, journal, and article that support the argument of the writer.

In analyzing and obtaining the data regarding racism discrimination in 12 years a slave movie the writer used genetic structuralism to describe racist in the movie. The approach is used intrinsic and extrinsic unsure for the work. The Description of racism in 12 Years a Slave movie using genetic structuralism is described below:

1. Selecting and sorting the data (primary data and secondary data).

2. Identifying the primary data taken from the 12 Years a Slave novel.

3. Identifying secondary data such as books, journals, and articles that related to the novel.

4. Finding kind of racism discrimination to American African people in 12 Years a Slave novel.

5. Describe racism development in the 12 Years a Slave novel

\section{Findings and Discussion}

In this chapter, the author consisted of the racism discrimination to the black people in 12 Years a slave with relationship to racism theory

\section{Racism by Verbal}

According to Rodney Clark, there are 2 conceptual of racism, drafted into two concepts of racism in society first was the attitude and the second was behavioral [5].

\section{Attitude Racism}

This concept has been used to represent attitudes of particular groups that have the power to rule the minority group. The concept of attitude was talked about how white as the superior group treat black as the lower group, this concept can be described and give a reason why different acts that shown by a majority group to a minority group. It has been found that white and black people were separated by the color of skin, the different attitude we can see from dialogue that said by the character, we can find obviously white pressure the black from the words that white choice when 
they talk to black. This way is also considered as the act to make black obedient to the ordered from the master, but this act also can be categorized as the way to confirm their position in social structure. Consider their position as the highest level in the social structure make white can tell everything they want to say. Some dialogue of white man communicated to black was followed by yelling, mocking, and humiliated black, this attitude was represented by Mr. Tibeats, Mr. Freeman, and Mr. and Mrs. Epps.

\section{Behavioral Racism}

Behavioral racism, in contrast, was an act of an individual or group that denies equitable treatment to an individual or a group because of phenotypic characteristics or ethnic groups. Differences with the attitude that just focus on how white treat black behavioral deeply into society [5]. We find some people who treat and talk with black politely enough that character was represented by Mr. Ford the first master of Platt. It shows some protagonist white characters where they treat African Americans well enough even though they were treated a slave human enough but the racism is still there. McQueen was shown the protagonist white character that makes a relation to black but American behavior in treating black like an animal has made the protagonist do a different action. White just treat black well if they still give a benefit for them but if it has done, they will be sold or exchanged them. The point is the white doesn't care about the black fate they just treat them well to make them comfortable working with them, despite all of that they still consider black as property or animal.

\section{Non-Verbal Racism}

Non-verbal racism was the kind of racism that was described as the attitude, prejudice, and behavior of a particular group to another group. In 12 Years A Slave, We find racial acts that show in the daily activities of white people and how they behave to people from another group. The racial discrimination that was done without awareness, these acts include from the way they look, the way they move until their respond to black people. The writers distinguished this action into two parts, first, the economic reason, and the second was the prejudice reason.

\section{Economic Reason}

Racism appeared because those reasons followed by the history of why the white has moved to the united stated. Escape from the pressures of the king and People who go to the American average dating and plantations in America. As the American colonization of the State was still heavily dependent on the UK, the kingdom at that time always sent slaves to America as slaves employed in the fields. UK as the partner of U.S.A in developing economy in each country was doing some exchanged, the UK will send slaves that brought from Africa to America for hire in plantation or factory and for reward the UK ask crops from the Plantation those system known as triangular trade [13]. We can identify that Mr. Ford was one of the men who treat the black well just for business, he tried to get loyalty from his slave but when talking about money Mr. Ford have another vision, he will look at his slave as property and business, and also he was thinking about profit and loss his debt. The reaction of Mr. Ford when he put Platt on the floor was the sign that they don't care about black fate. We find some good attitude characters like Mr. Ford but even though he was a good man, racism still appears among slaves and his master.

\section{Projudice Reason}

This kind of racism appear because white people were beliefs the myth about evolution. The theory that supports racism was the theory from Charles Darwin, even in present-day his theory no longer applies but in first appear his theory makes people believe that there was no equality because some kind of human has evolved perfectly than others kind. Pressures between Tibeats and Solomon never return to normal, and they have another unsafe experience where Solomon is about hanged. Tibeats offers Solomon to Edwin Epps, a man who gloats of his capacity to break slaves [12]. White people beliefs Europeans were the perfect evolution of humans and has a right to rule the others. According to Harun, the white people were beliefs that Africans were a primitive race and race that used power than a mind [14].

In 12 Years a Slave shows what white people can do to anything to black people when they cannot obey the master's will. There are two young black people who get chained because they have done something wrong or they no follow the instruction of their master, on their back we can see the scar, that scar was made by whipping. Then, there is Patsy lash until breaks flesh in her back, this act was done by Mr. Epps. Patsy was the girl that become the partner of Platt in Mr. Epps Plantation. Violence was done by white people to give a lesson to black people if they do an action without instruction from the master, and violence was done to make black realize the position of them as the lowest class in social structure 


\section{Conclusion}

Based on the analysis in the previous chapter, the writer finds some conclusions they are: The kind of racism showed in 12 Years a Slave was racism from the lowest level to the highest level. The lowest level was the racism by using words or verbal way and the highest was the non-verbal one, this act including response, behavior, and violence. Economic reasons were the first reason which discriminate using the capitalist system. Both are political reasons used by white people to show their superiority to other races with enslaving black skin and the third was the reason the myth and history, discriminate unconsciously because already familiar with the existing culture.

Racism is a kind of distinguisher of a dominant race to inferior races [15]. The novel gives a lesson that all men have the same right to be happy, to enjoy what they like and what they want. The life of every human race as the valuable distinction between race and ethnicity will only create the gaps in between them which will lead to a conflict between races.

12 Years a Slave itself also shows that not everyone can be smart but smart people can come from anywhere. Pressure the same existence of slow development of civilization of a race that could be the race that could help the other races to develop human civilization. Racism can also be portrayed in every corner of the world, even, in South Sulawesi where the writer of this research lived in. In a region of South Sulawesi, Makassar, racism has appeared between local ethnic to another ethnic for instance, People who come from Flores and Java was discriminated by verbal, sometimes they were called "Jawa" for people from Java and "Bangsa Hitam" refer to people from Flores.

\section{Acknowledgements}

The writer would like to express his gratitude to his partner for helping to elaborate the main problem in life, like this Racism and it also would not be happened if the writers cannot be helped by useful data as well as the sources to help obtain the findings in this research.

\section{References}

[1] Faruk, Pengantar Sosiologi Sastra, edition (4). Yogyakarta: Pustaka Pelajar, 2014

[2] R. Wellek \& A. Warren, "Theory of Literature”, $5^{\text {th }}$ edition, Jakarta: Gramedia, 1962.

[3] B. Lawrence. (2003). Race, Racism, and Discrimination: Bridging Problems, Methods, and Theory in Social Psychological Research.

[4] David. (2013). To Kill a Mockingbird by Harper Lee - review [Online]. Available: https : //www . theguardian.com/ books/2013/oct/17/review-to-kill-a-mockingbird-harper-lee

[5] R. Clark. (1999). Biopsychosocial: Racism as a stressor for African American.

[6] L. Goldmann, Towards a Sociology of the Novel, England: Cambridge University, 1964

[7] A. Reynaldi., "The Analysis of Racism Discrimination in Steve McQueen's Movie "12 Years a Slave"," Thesis, FBS., UNM., Makassar., Indonesia, 2016.

[8] CliffNotes. (2021). 12 Years A Slave [Online]. Available: https://www.cliffsnotes.com/literature/t/ twelve-years-a-slave/summary-and-analysis/editors-preface

[9] Angel and K.S. Newman, Discrimination in an Unequal World, A book, England, Oxford University, 2010.

[10] R. Moore. (2014). Solomon Northup Day [Online]. Available: https://www.britannica.com/topic/ Solomon-Northup-Day\#ref 1201308

[11] S. Churchwell. (2014). 12 Years a Slave: the book behind the film [Online]. Available: https: //www . theguardian. com/books/2014/jan/10/12-years-slave-uncle-toms-cabin

[12] Gradesaver. Twelve Years a Slave Summary [Online]. Available: https://www.gradesaver.com/ twelve-years-a-slave/study-guide/summary

[13] S. Oktoviana. (2011). Sejarah Perbudakan di Amerika. Available: https://kompasiana.com

[14] Y. Harun. (2015). Rasisme dan Kolonialisme [Online]. Available: http://ivanugm . web.ugm.ac.id/Artikel/TZ/ Evolusi, \%20Rasisme, \%20dan\%20Kolonialisme.html.

[15] [Lexico. (2016). Racism [Online]. Available: http://www.oxforddictionaries.com/definition/english/racism 